\title{
Assessment of Indoor Ionizing Radiation Profile in Radiology Department FMC Asaba Delta State, Nigeria
}

\author{
${ }^{1}$ Abubakar A., ${ }^{2}$ Sadiq AA., ${ }^{1}$ Musa MG., ${ }^{1}$ Hassan J., ${ }^{1}$ Malgwi DF. \\ ${ }^{I}$ Department of medical Radiography, College of Medical Sciences, University of Maiduguri, \\ Borno State Nigeria \\ ${ }^{2}$ Department of Radiography, Faculty of Clinical Sciences, College of Health Sciences, \\ Usmanu Danfodiyo University Sokoto (UDUS), Nigeria
}

Corresponding author: Abubakar A.

Email: a.abubakar@unimaid.edu.ng

Mobile number: +2347063898690

\begin{abstract}
A "Radiation Alert Inspector" survey meter was the instrument of choice used in measuring and obtaining the indoor ionizing radiation profile placed at 22 selected presumable hotspots of increase radiation (coded A1-A22) as identified by a global positioning system within the Radiology department of Federal Medical Centre (FMC) Asaba. Values obtained from the measurements were converted from micro Sievert per hour $(\mu \mathrm{Sv} / \mathrm{hr}$ ) to mili Sievert per year ( $\mathrm{mSv} / \mathrm{yr}$ ). The calculated mean indoor post exposure dose value was in the range of $0.09-0.20 \mu \mathrm{Sv} / \mathrm{hr}(0.60-2.01 \mathrm{mSv} / \mathrm{yr})$. The highest point with increased radiation dose was found to be in the diagnostic $x$-ray room $(2.01 \pm 4.11 \mathrm{mSv} / \mathrm{yr})$, while the lowest point was detected at the intern's common room with a value of $0.60 \pm 0.3 \mathrm{mSv} / \mathrm{yr}$. The overall mean of the Mean Indoor Post Exposure (mMIPE) was arrived at $0.88 \pm 0.28 \mathrm{mSv} / \mathrm{yr}$. Base on the aforementioned findings, it was deduced that radiation level were kept within permissible radiation limit as stipulated by the ICRP and UNSCEAR of $1 \mathrm{mSv} / \mathrm{yr}$ and thus, FMC Asaba can be said to be Radiologically safe.
\end{abstract}

Keywords: Indoor ionizing radiation, Micro/mili Sievert ( $\mu / \mathrm{mSv})$, Radiation, Dose, patient

\section{Introduction}

We meet radiation in our daily lives in different forms and intensities (Solomon et al., 2000, IAEA, 2004). Radiation is generally categorized into ionizing and non-ionizing radiation. Ionizing radiation have energies sufficient enough to eject biologic molecules e.g. cosmic, protons, neutrons, alpha, beta, gamma and xrays, while non-ionizing radiation cannot ionize biologic molecules owing to their low energies e.g. ultraviolet (UV-A \& UV-B) visible ray, microwave, infra-red and Radiofrequency (RF) wave (Karma and Erondu, 2012).

Natural or background radiation is the radiation of man's natural environment and categorized into 3 types namely primordial, cosmogenic and anthropogenic. Primordial sources are found in the earth's crust and in the general environment; cosmogenic is when cosmic rays interacts with elements in the atmosphere and eventually gets deposited on both wet and dry depositions. Anthropogenic sources are regarded as background sources due to their presence everywhere (UNSCEAR, 2008).

It has been estimated that around $82-85 \%$ of man's exposure to ionizing radiation generally comes from natural sources and depending on the geology, altitude, construction material used and diet; man's average dose per annum is around $1-3 \mathrm{mSv}$. Radioactive nuclide from the earth crust forms a larger part of the background radiation. E.g. ${ }^{40}$ potassium, ${ }^{238}$ Uranium, ${ }^{232}$ Thorium, ${ }^{87}$ Rubidium, ${ }^{222}$ Radium, (Appleton, 2004; Briggs-Kamara \& Erondu, 2012). Apart from the natural sources of radiation exposed to man, an estimate of 18$20 \%$ of ionizing radiation are generated as a result of scientific and technological improvements, out of which medical uses (for diagnosis and therapy) form the majority (WNA 2015; ATSDR, 2015).

$\mathrm{X}$-radiation forms the largest source of man-made radiation to the world population due to this, its effect has been broadly divided into stochastic and non-stochastic (IAEA, 2003), Stochastic effect have no threshold of occurrence while non-stochastic effects have threshold values of occurrence below which no effect is demonstrated (ICRP, 2005).

Radiation induced injuries like erythema and ulcerations to the skin were the first earliest reported cases in 1896, while cases like cancer of the skin were reported in 1902 (Briggs-Kamara \& Erondu, 2012). In 114 documented cancer cases, medical and technical staff were mostly affected, while a documented case of 359 radiologist died due to radiation induced cancer of the skin and bone. The effects of ionizing radiation has been known at higher levels with an ongoing debate as to whether it has beneficial effects at low levels (radiation hormesis) (Chad-Umoren et al., 2006; Fairlie, 2013). 
Several studies has been conducted in different parts of Nigeria to ascertain levels of environmental ionizing radiation and its possible health effect on the public, as such, this study aims to assess the level of indoor ionizing radiation at the federal medical centre Asaba and to compare the findings with documented guidelines on radiation protection and safety.

\section{Methodology}

A well calibrated pocket sized "Radiation Alert Inspector" survey meter with serial number 15823 USA, was the instrument used in measuring the indoor ionizing radiation profile for this study; it was fully optimized with ability to detect low levels of different radiation (alpha, beta, gamma and x-rays). The radiation inspector uses a pancake tube which is a 2 -inch window Geiger tube. On the front is a small radiation symbol signifying the centre of the Geiger tube. A global positioning system was used to determine the position for the data collection. The study was carried out at the department of Radiology Federal Medical Centre (FMC), Asaba, Delta state for a period of six months commencing from November 2015 - May, 2016. A prospective experimental study design was used. Twenty-two points were selected of presumable high radiation dose using convenient sampling technique. In the procedure for obtaining the data, the radiation inspector was positioned at $1 \mathrm{~m}$ above the ground level and $6 \mathrm{~cm}$ from the wall for uniformity (Chad-Umoren et al., 2006; Sadiq \& Agba, 2012). Three readings were recorded for both background and post exposure measurements of the selected points. For measurements of the post exposure, the factors utilized were ones used for chest X-ray of an average $70 \mathrm{~kg}$ patient under erect conditions for the background readings. It was obtained when no exposure was going on at all or when the machines were switched off. With the said meter in position during exposure and measurements recorded 10 seconds after termination of the exposure button, the post exposure measurement was obtained.

A data captured sheet was used in recording values obtained. The equivalent dose readings were initially recorded in mili-Roentgen per hour $(\mathrm{mR} / \mathrm{hr})$ and converted into micro-Sievert per hour $(\mu \mathrm{Sv} / \mathrm{hr})$, then to mili-Sievert per year (mSv/yr). An occupancy factor of 0.8 was recommended by the UNSCEAR (2000). The number of hour in a year was calculated based on 24 hour a day and multiplied by 365 days in a year = $8760 \mathrm{hr} / \mathrm{yr}$

To convert the dose rate from $\mu \mathrm{Sv} / \mathrm{hr}$ to $\mathrm{mSv} / \mathrm{yr}$; Indoor $=\mathrm{X} \mu \mathrm{Sv} / \mathrm{hr} \times 8760 \times 0.8=$ Mean Indoor per year.

All data were analysed using SPSS version 16.0 (SPSS. Inc Chicago USA)

\section{Result}

Table 1. Shows result of the Mean Indoor Background dose rate (MIB) and the Mean Indoor Post Exposure (MIPE) dose equivalent values in $\mu \mathrm{Sv} / \mathrm{hr}$ and their conversions into $\mathrm{mSv} / \mathrm{year}$. The mean indoor background values ranged from $0.09-0.14 \mu \mathrm{sv} / \mathrm{hr}(0.66-0.97 \mathrm{msv} / \mathrm{yr})$. The overall mean MIB reading was $0.11 \pm 0.01 \mu \mathrm{sv} / \mathrm{hr}(0.79 \pm 0.79 \mathrm{msv} / \mathrm{yr})$.

The values for the mean indoor background readings were consistently lower than the mean indoor post exposure readings.

The mean indoor post exposure dose equivalent readings ranged from $0.09-0.29 \mu \mathrm{Sv} / \mathrm{hr}(0.60$ to $2.01 \mathrm{mSv} /$ year). The lowest reading obtained was from the intern's common room of $0.60 \pm 0.31 \mathrm{mSv} /$ year, and the highest reading of $2.01 \pm 4.11 \mathrm{mSv} /$ year was obtained at a point in the diagnostic $\mathrm{x}$-ray room 1 . However the mean for MIPE was $0.88 \pm 0.28 \mathrm{mSv} /$ year.

Table 2. Shows a comparison of the readings recorded in this study with other readings obtained in other studies in various locations in Nigeria. 
Table 1. Shows Indoor dose equivalent reading

\begin{tabular}{|c|c|c|c|c|c|c|c|}
\hline \multirow[b]{2}{*}{$\begin{array}{l}\text { Points } \\
\text { Code }\end{array}$} & \multirow[b]{2}{*}{ Sampling locationx } & \multirow[b]{2}{*}{$\begin{array}{l}\text { Gobal Pontioning } \\
\text { System(GrS) } \\
\text { Reading }\end{array}$} & \multirow[b]{2}{*}{$\begin{array}{l}\text { Distance } \\
\text { froux } x \text {-ray } \\
\text { source(m) }\end{array}$} & \multicolumn{2}{|c|}{ 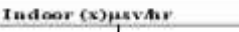 } & \multicolumn{2}{|c|}{ Indoerr $\left(x_{1}\right) \operatorname{mov} / y$. } \\
\hline & & & & Mun: & MHIVE: & мแน" & MHIE: \\
\hline AI & X-ray room 1 & $6289^{4} \times, 6725^{\circ} \mathrm{E}$ & 3.28 & $0.11+0.52$ & $0.29+411$ & $0,75-0.94$ & $201-411$ \\
\hline$A^{2}$ & X-ray room 2 & $\begin{array}{l}117^{\circ} 8 \mathrm{~g} \\
6.212^{\circ}, 6.712 \mathrm{E}\end{array}$ & 2.00 & $0.12 \div 0.71$ & $0.12=0.22$ & $0.86=0.84$ & $0.81=0.22$ \\
\hline $\mathrm{A3}$ & $\begin{array}{l}\text { Radiographer's } \\
\text { console }\end{array}$ & $6.212^{4} \mathrm{~N}, 0.712^{4} \mathrm{E}$ & 3.05 & $0.11=0.34$ & $0.14=0.13$ & $0.70=0.42$ & $0.92 \pm 0.13$ \\
\hline A4 & Corrider point 1 & . & 3.97 & $0.10=1.03$ & $0.10=0.26$ & $0.71=1.04$ & $0.72 \div 0.26$ \\
\hline As & $\begin{array}{l}\text { Chier } \\
\text { radiographers. } \\
\text { afnes }\end{array}$ & 21, & 3.39 & $0.11 \pm 0.17$ & $0.13=0.10$ & $0.78=0.17$ & $0.24 \pm 0.10$ \\
\hline $\mathrm{A}^{6}$ & Seminar room & 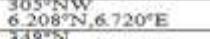 & 4.00 & $0.10-1.04$ & $0.13 \div 0.19$ & $0.71-1.04$ & $0.88 \div 0.19$ \\
\hline A7 & Reception & 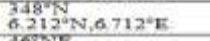 & 1000 & $0.11=052$ & $0.13<0.10$ & $0.75+0.54$ & 0.9820 .10 \\
\hline $\mathrm{x}^{\mathrm{B}}$ & Corridor poimt 2 & $6.212^{\circ} \mathrm{N}, 6.711^{\circ} \mathrm{E}$ & 4.00 & $0.13 \div 1.75$ & $0.11+0.24$ & $0.93+1.72$ & $0.76+0.24$ \\
\hline A9 & $\begin{array}{l}\text { Reswit prieciong } \\
\text { area }\end{array}$ & $\begin{array}{l}133985 \\
62074 \mathrm{~N}, 6.725 \mathrm{~V}\end{array}$ & 10.00 & $0.09+1.69$ & $0.14=0.19$ & $0.66-1,67$ & $0.95=0.16$ \\
\hline 810 & Entrance & $625^{\circ} 8 \mathrm{~W}, 6712^{\circ} \mathrm{E}$ & 17.5 & $0.11 \div 0.25$ & $0.12+0.20$ & $0.77 \approx 0.29$ & $0.86 \div 0.20$ \\
\hline $\mathrm{Am}$ & Vltrasema suite & $6212^{\circ} \mathrm{N}, 6711^{\circ} \mathrm{K}$ & 7.43 & 0.1240 .18 & $0.10+0.28$ & $0.81-0.21$ & $0.68+0.28$ \\
\hline $\mathrm{X12}$ & Dipitizer room & $\begin{array}{l}149^{295} \\
6.213^{\circ} \mathrm{N}, 6.712^{\circ} \mathrm{E}\end{array}$ & 4.06 & $0.11+0.01$ & $0.12+0.21$ & $0.80=0.09$ & $0.83+0.21$ \\
\hline A) & Dark raom & 6312WN, $67124 \mathrm{~F}$ & 12.05 & $0,14-2.28$ & $0,10+0,26$ & $0.97+2.22$ & $0.73 \div 0.26$ \\
\hline Alit & $\begin{array}{l}\text { Patient waitiag } \\
\text { area I }\end{array}$ & $62125,6.720 \mathrm{E}$ & 1490 & $0.12=0.71$ & $0.10 \pm 0.26$ & $0.85 \pm 0.71$ & $0.71=0.26$ \\
\hline A15 & $\begin{array}{l}\text { Patient wainial } \\
\text { area } 2\end{array}$ & $\begin{array}{l}3120 \mathrm{NW} \\
6.212 \%, 6.720 \mathrm{E}\end{array}$ & 15.00 & $0.11=0.43$ & $0.10 \div 0.26$ & $0.76 \pm 0.42$ & $0.71=0.26$ \\
\hline A16 & Call raom & $\begin{array}{l}346 \% \mathrm{~N} \\
6.2076 \mathrm{~N}, 6.725 \cdot \mathrm{E}\end{array}$ & 17.90 & $0.10=0.70$ & $0.11=0.23$ & $0.74 \pm 0.67$ & $0.78 \pm 0.23$ \\
\hline A17 & $\begin{array}{l}\text { Isterns common } \\
\text { room }\end{array}$ & $\begin{array}{l}128^{6 S E} \\
6.212^{\circ} \mathrm{N}, 6.711^{\circ} \mathrm{E}\end{array}$ & 6.18 & $0.11=0.52$ & $0.09 \pm 0.31$ & $0.75 \times 0.54$ & $0.60=0.31$ \\
\hline A18 & $\begin{array}{l}\text { Radiogrixphers' } \\
\text { common room }\end{array}$ & $\begin{array}{l}227^{\circ} \mathrm{SW} \\
6.212^{\circ} \mathrm{N} .6120 \mathrm{E}\end{array}$ & 8.45 & $0.13 \div 1.23$ & $0.11 * 0.23$ & 0.8941 .21 & $0.78+0.23$ \\
\hline A19 & $\begin{array}{l}\text { Registration/reauli } \\
\text { collection area }\end{array}$ & $\begin{array}{l}353 / 2 \\
6213^{6}, 6.712 \mathrm{E}\end{array}$ & 1460 & $0.13+1.23$ & $0.12+0.20$ & $0.89+1.21$ & $0.85 \div 0.20$ \\
\hline$A 20$ & HOD'S effice & $\begin{array}{l}21605 \mathrm{~W} \\
6.2120 \mathrm{~N}, 6.711^{\circ} \mathrm{E}\end{array}$ & 4.03 & $0.12=0.79$ & $0.14 \pm 0.14$ & $0 . \$ 6 \pm 0.84$ & $100 \pm 0.14$ \\
\hline$A 21$ & DRS's office & $\begin{array}{l}2278 \mathrm{sW} \\
6.212^{\circ} \mathrm{N} .6711^{\circ} \mathrm{E}\end{array}$ & 808 & 0.100095 & 0.1440 .14 & $0.72+0.92$ & $100-0.14$ \\
\hline A22 & $\begin{array}{l}\text { Esit point } \\
\text { Mean }\end{array}$ & $\begin{array}{l}44 \mathrm{NE} \\
62130 \mathrm{~N}, 67120 \mathrm{E}\end{array}$ & 7.15 & $\frac{0.10=0.78}{0.11=0.01}$ & $\frac{0.13+0.18}{0.13=0.04}$ & $\frac{0.73+0.79}{0.79 \pm 0.79}$ & $\frac{0.90-0.20}{0.88=0.28}$ \\
\hline
\end{tabular}

MIB - Mean Indoor Background readings

MIPE -Mean Indoor Post Exposure readings

Table 2: Compares present study readings with previously conducted studies in Nigeria

\begin{tabular}{|c|c|c|}
\hline LOCATIONS & INDOOR & REFERENCE \\
\hline Maiduguri, Borno state & $\begin{array}{l}0.05 \pm 0.01 \mu \mathrm{sv} / \mathrm{hr} \\
(0.36 \pm 0.001 \mathrm{msv} / \mathrm{yr})\end{array}$ & Okedayo et al.,2015 \\
\hline $\begin{array}{ll}\text { Bori, Rivers state } & \text { (i) } \\
& \text { (ii) }\end{array}$ & $\begin{array}{l}0.93 \pm 0.13 \mathrm{msv} / \mathrm{yr} \\
1.22 \pm 0.10 \mathrm{msv} / \mathrm{yr}\end{array}$ & Ononugbo \& Nwic 2015 \\
\hline Jos-A & $\begin{array}{l}2.111 \mathrm{msv} / \mathrm{yr} \\
2.733 \mathrm{msv} / \mathrm{yr}\end{array}$ & Jwanbot et al., 2012 \\
\hline Kwali, Abuja & $0.107 \pm 0.003$ & James et al., 2015 \\
\hline Jos-B & $\begin{array}{l}0.256 \mu \mathrm{sv} / \mathrm{hr} \\
(1.54 \mathrm{msv} / \mathrm{hr})\end{array}$ & Masok et al., 2015 \\
\hline Illorin, Kwara state & $1.60 \pm 0.26 \mathrm{msv} / \mathrm{yr}$ & Nwankwo et al., 2014 \\
\hline Keffi, Nassarawa state & $1.08 \mathrm{msv} / \mathrm{yr}$ & Sadiq\&Agba 2012 \\
\hline Port Harcourt, Rivers state & $0.146 \pm 0.02$ & Okoye et al., 2013 \\
\hline Lagos-A & $0.2-2 \mu \mathrm{sv} / \mathrm{hr}$ & Oluwafisoye et al., 2010 \\
\hline Lagos-B & $0.2-1.5 \mu \mathrm{sv} / \mathrm{hr}$ & Oluwafisoye et al., 2010 \\
\hline Asaba, Delta state & $\begin{array}{l}0.13 \pm 0.04 \mu \mathrm{sv} / \mathrm{hr} \\
(0.88 \pm 0.28 \mathrm{msv} / \mathrm{yr})\end{array}$ & Current study \\
\hline
\end{tabular}

\section{Discussion}

In the study conducted, the mean indoor post exposure (MIPE) values obtained were consistently higher than the mean indoor background (MIB) values except for the MIB value recorded at a point in the darkroom $(0.97 \pm 2.22)$. The average difference between the mean indoor post exposure (MIPE) and mean indoor background (MIB) radiation dose is $0.09 \mathrm{msv} /$ year.

The results obtained were still below the limits of $1 \mathrm{msv} / \mathrm{year}$ as recommended by UNSCEAR and ICRP for radiation exposure of the general public globally (European Commission, 1999; ICRP, 2005; EPA, 2014).

The findings recorded in this study were still lower as compared to findings conducted to determine the indoor radiation exposure in various parts of Nigeria, (Ononugbo \& Nwic, 2015; Jwanbot et al., 2012; Nwankwo et al., 2014; Sadiq \& Agba, 2012). 
This may be due to the geological factors and type of building materials used, (Hulka et al., 2008).In places like Jos, Plateau state, where previous mining activities were carried out, it may not be surprising of detecting increased levels of radioactivity (Jwanbot et al., 2012), whereas, mining activities was never conducted in this area of study.

Although, readings acquired in this study were still within the low dose range of exposure, however, it could be considered significant because the study was carried out when only Conventional Radiography procedures were accomplished. This has been documented in a study by Fazel et al., (2009), to contribute to around $10 \%$ of the effective radiation per dose. Higher readings should be expected when computed tomography (CT) and nuclear medicine units are in place and use (Fazel et al., 2009).

Quality control and assurance testing is recommended to continuously assess the functionality of the $\mathrm{x}$ ray equipment in this locality.

However, studies carried out in the North Eastern part of Nigeria by Okedayo et al., (2015), reported lower readings than the result obtained in this study, this could be due to variation in geographical location/conditions and/or equipment used.

\section{Conclusion}

In the study conducted, it shows that the mean indoor background (MIB) reading to be lower than the mean indoor post-exposure radiation dose level, but below the internally recognized standard values. The post exposure dose level is also seen below values established in a number of radiology units in Nigeria. Thus, F.M.C, Asaba is considered Radiologically safe.

As part of recommendation, regular and periodic monitoring of the background ionizing radiation level is recommended to assess the health risk of staff, patients and the general public. Outdoor background radiation profile level should also be assessed and the radioactivity index of the building materials used in the structural construction of the department should be evaluated.

\section{References}

[1]. Appleton, D. (2004). Natural Radioactivity and Health. The Risks Posed by Exposure to Ionizing Radiation. Earthwise - British Geological Survey NERC, 21, 16-17.

[2]. Agency for Toxic Substances and Disease Registry (ATSDR). (2015). Sources of Population Exposure to Ionizing Radiation. Department of Health and Human Services. Atlanta G A: Agency for Toxic Substances \& Disease Registry.

[3]. Briggs-Kamara,M.A. Erondu, F.O., (2012). Fundamental of Radiation Detection, Dosimetry and Radiobiology. Owerri: Book-konzult.

[4]. Chad-Umoren, Y. E., Adekanmbi, M., \& Harry, S. O. (2006). Evaluation of indoor background Ionizing Radiation Profile of a Physics Laboratory. Working and Living Environmental Protection, 3(1), 1-8

[5]. Environmental Protection Agency (EPA). (2014). Radiation Protection Guidance for Diagnostic and Interventional X-Ray Procedures. Washington DC 20460: International Working Group on Medical Radiation - United State Environmental Protection Agency.

[6]. European Commission (1999). Radiological Protection Principles concerning the Natural Radioactivity of Building materials. STUK Finland: Directorate General, Environment Nuclear Safety and Civil Protection.

[7]. Fairlie I, (2013). Recent evidence on the Risk of very Low Level Radiation. Obtained from http//www.ianfailie.org

[8]. Fazel, R., Krumholz, H. M., Wang, Y., \& Jersey, C. (2009). Exposure to Low Dose ionizing Radiation from Medical Imaging Procedures. The New journal of Medicine, 361(9), 849-857.

[9]. Hulka, J., Vlcek, J., \& Thomas J. (2008). Natural Radioactivity in Building materials - Czech experience and European Legislation. Las Vegas: American Association of Radon Scintists and Technologists - International Symbosium

[10]. IAEA (International Atomic Energy Agency), (2003). Security of Radioactive sources. Vienna, 10-13 March 2003.

[11]. IAEA (International Atomic Energy Agency), (2004). Radiation, People and the Environment. Austria, February 2004. IAEA: Austria.

[12]. International Commission on Radiation Protection (ICRP) (2005, January 27). Do we significantly underestimate or overestimate Radiological Risks. Bern, Switzerland international Commission on Radiation Protection

[13]. James, et al., (2015). Measurement of Indoor and Outdoor Background Ionizing Radiations of Kwali General Hospital, Abuja. Journal of Applied Science and Environmental Management. 19(1) 89-93.

[14]. Jwanbot, D. I; Izam, M. M; Nyam G. G; Agada, I. S (2012). Evaluation of Indoor background ionising radiation profile in some hospitals in Jos Plateau state Nigeria. Journal of Natural Sciences Research 2 (7): 35-40.

[15]. Masok, et al., (2015). Assessment of Indoor and Outdoor Background Radiation Level in Plateau State University Bokkos, Jos, Nigeria. Journal of Environment and Earth Science.

[16]. Nwankwo L.I, Adeoti D.F, Folarin A.J., (2014). Ionizing Radiation Measurements and Assay of Corresponding Dose Rate around Bottling and Pharmaceutical Facilities in Ilorin, Nigeria. Journal of Science and Technology, volume .34, No. 2,Pp. 84-92.

[17]. Oluwafisoye, P. A., Olowookere, C. J., Jibiri, N. N., Bello, T. O., Alausa, S. K., \&Efunwole, H. O. (2010, May). Quality Control and Environmental Assessment of Equipment used in Diagnostic Radiology. International Journal of Research and Reviews in Applied Sciences, 3(2), 148- 158

[18]. Onougbo et al., (2015). Indoor And Outdoor Effective Doses From Background Ionizing Radiation In Private Medical Diagnostic Centres In Bori, Rivers State. Journal of Environmental and Earth Science.

[19]. Okedayo, et al., (2015). Ambient Ionizing Radiation Assessment And Its Public Health Implication at Radiology Department, University Of Maiduguri Teaching Hospital, Borno State, Nigeria. Researchjournali's Journal of Public Health.

[20]. Sadiq, A. A., \&Agba, E. H. (2012). Indoor and Outdoor Ambient Radiation Levels in Keffi Nigeria. facta university Series: Working and Living Environmental Protection, 9(2), 19-26.

[21]. Solomon, et al., (2000). National Background Radiation Characteristics of Basalt on the Jos Plateau and the Radiological implication of the use of the Rock for House Construction. African Journal of Natural Science, 5.

[22]. UNSCEAR (2000). United Nation Scientific Committee on the Effects of Atomic Radiation. Sources and effect of Ionizing radiation. Report to the general assembly with scientific annexes. United Nations; New York.

[23]. UNSCEAR (2008). Souces and Effects of Ionizing Radiation. Report to the General Assembly with Scientific Annexes, vol. 1.

[24]. World Nuclear Association (WNA). (2015). Nuclear Radiation and Health Effects. London: World Nuclear Association 